\title{
Generation and evaluation of pharmacologically relevant drug-drug cocrystal for gout therapy
}

\author{
Sheela Modani ${ }^{\mathrm{a}}$, Anilkumar Gunnam ${ }^{\mathrm{b}}$, Balvant Yadav ${ }^{\mathrm{a}}$, Ashwini K. Nangia ${ }^{\mathrm{bc}}$, \\ Nalini R Shastria*
}

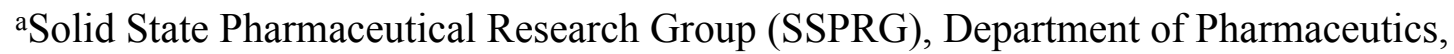
National Institute of Pharmaceutical Education and Research (NIPER), Hyderabad, 500037, India.

${ }^{b}$ School of Chemistry, University of Hyderabad, Central University PO, Prof. C. R. Rao Road, Hyderabad, India

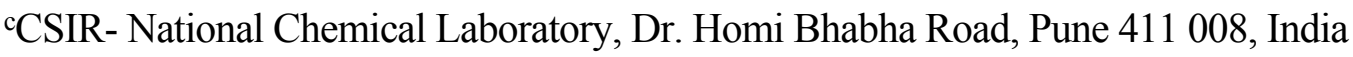

* Corresponding author. Nalini R Shastri

Tel. +91-040-23423749

Fax. +91-040-23073751

E-mail: nalini.niperhyd@gmail.com, svcphod@yahoo.co.in,

Address: Department of Pharmaceutics, National Institute of Pharmaceutical Education \& Research (NIPER), Balanagar, Hyderabad, India, Pin code - 500037 


\section{SUPPORTING INFORMATION}

\section{Materials}

Febuxostat (FBX) was kindly gifted by Dr. Reddy's Laboratories, Hyderabad, India. Piroxicam (PXM) was obtained as a gift sample from Apex Healthcare Limited, Ankleshwar, Gujarat. Acetonitrile were purchased from Merck life sciences Pvt. Ltd, Mumbai.

\section{Experimental Methods}

\section{Preparation of cocrystals}

Preliminary screening for novel solid form was carried out by grinding drug and coformer together at an ambient temperature. A mixture of $40 \mathrm{mg}$ of FBX and $41.89 \mathrm{mg}$ of PXM corresponding to 1:1 mole ratio were ground together for $30 \mathrm{~min}$ in agate mortar in presence of $100 \mu \mathrm{L}$ of acetone. Crystallization experiments were carried out by dissolving a mixture of $40 \mathrm{mg}$ of FBX and $41.89 \mathrm{mg}$ of PXM (1:1 mole ratio) in acetonitrile. Further, the beaker was covered with pin-holed aluminum foil and left at room temperature facilitating slow evaporation of the solvent. Single crystals obtained after 3-5 days were filtered, air-dried, and stored in a glass vial until further analysis.

\section{Characterization of cocrystals}

\section{Melting point}

Melting point was determined using melting point apparatus Stuart ${ }^{\circledR}$ SMP30 by the capillary melting method.

\section{Differential scanning calorimetry (DSC)}

Thermal analysis of samples was performed using Mettler Toledo DSC (STAR ${ }^{\mathrm{e}}$ SW 13.00 software) which was calibrated using indium. The accurately weighed sample was placed in hermetically sealed aluminum crimped pans. The sample was heated at a rate $10^{\circ} \mathrm{C} / \mathrm{min}$ and scanned from $20^{\circ} \mathrm{C}$ to $230^{\circ} \mathrm{C}$ during which dry nitrogen gas was purged through the DSC chamber at $60 \mathrm{~mL} / \mathrm{min}$.

\section{Attenuated total reflectance-Fourier transform infrared spectroscopy (ATR-FTIR)}

IR spectra of samples obtained from solvent evaporation were measured using Perkin Elmer IR spectrophotometer. About 5 to $10 \mathrm{mg}$ sample was directly placed on diamond crystal surface for surface analysis. The IR spectra data was recorded over the range of 500 to 4000 $\mathrm{cm}^{-1}$ by an accumulation of 16 scans. 


\section{Powder X-ray Diffraction (PXRD)}

PXRD measurements were performed using a PANalytical X'Pert PRO X-ray Powder Diffractometer (Eindhoven, Netherlands), using Ni-filtered $\mathrm{Cu}$ K $\alpha$ radiation $(\lambda=1.5406 \AA)$. The PXRD patterns were recorded over a scanning $2 \theta$ range of $5^{\circ}$ to $50^{\circ}$ at step time of 0.045 steps $/ 0.5 \mathrm{~s}$.

\section{Single crystal X-ray diffraction}

The single crystal X-ray diffraction data were collected at $298 \mathrm{~K}$ for FBX-NSAID cocrystal. The measurements were conducted on Bruker D8 QUEST, CCD diffractometer equipped with a graphite monochromator and Mo-K $\alpha$ fine-focus sealed tube $(\lambda=0.71073 \AA)$ and a reduction was performed using APEX-II Software. The structure property relationship was established by studying the relative arrangement molecules and differences in inter-molecular interactions using Mercury software V4.1 CCDC.

\section{Analytical method development}

The analysis of FBX-PXM was carried out by reverse phase HPLC (Shimadzu, USA) which consists of an automated injector equipped with a dual wavelength UV detector and an autosampler. The data analysis was carried out by Lab Solutions software. Standards were prepared from a primary stock solution of $1000 \mu \mathrm{g} / \mathrm{mL}$. The primary stock was diluted to get a secondary stock of $100 \mu \mathrm{g} / \mathrm{mL}$. The secondary stock was diluted to get $10 \mu \mathrm{g} / \mathrm{mL}$. From the $10 \mu \mathrm{g} / \mathrm{mL}$ stock, different concentrations like $0.5,1,1.5,2$ and $2.5 \mu \mathrm{g} / \mathrm{mL}(\mathrm{n}=3)$ were prepared and injected in the column. The data analysis was carried out by Lab Solutions software. The chromatographic conditions for analysis are given in table S4 below.

\section{Solubility studies}

Solubility studies of drugs and cocrystal were determined by equilibrating excess amount of each drug in $3 \mathrm{~mL}$ of buffer solutions of $\mathrm{pH} 1.2,4.5,6.8,7.4$ and purified water. Incubator shaker was used to keep samples at $37^{\circ} \mathrm{C}$ during the test with agitation of $150 \mathrm{rpm}$ for 72 hours. After this period, samples were immediately filtered $(0.22 \mu \mathrm{m})$, diluted with the corresponding media and analyzed by HPLC method. ${ }^{1}$

\section{Buffer preparation for solubility studies ${ }^{2}$}


Preparation of pH 1.2 hydrochloric acid buffer: $50 \mathrm{~mL}$ of $0.2 \mathrm{M}$ potassium chloride $(\mathrm{KCl})$ and $85 \mathrm{~mL}$ of $0.2 \mathrm{M}$ Hydrochloric acid $(\mathrm{HCl})$ were mixed and the volume was adjusted to 200 $\mathrm{mL}$ with distilled water.

Preparation of pH 4.5 acetate buffer: $2.99 \mathrm{~g}$ of sodium acetate trihydrate $\left(\mathrm{NaC}_{2} \mathrm{H}_{3} \mathrm{O}_{2} .3 \mathrm{H}_{2} \mathrm{O}\right)$ and $14 \mathrm{~mL}$ of $2 \mathrm{~N}$ glacial acetic acid were mixed and $1000 \mathrm{~mL}$ volume was adjusted of distilled water.

Preparation of pH 6.8 phosphate buffer: $50 \mathrm{~mL}$ of $0.2 \mathrm{M}$ monobasic potassium phosphate (27.22 $\mathrm{g}$ of potassium dihydrogen phosphate $\left(\mathrm{KH}_{2} \mathrm{PO}_{4}\right)$ in water and dilute to $1000 \mathrm{~mL}$ ) and $22.4 \mathrm{~mL} 0.2 \mathrm{M}$ of sodium hydroxide $(\mathrm{NaOH})$ were mixed and the volume was adjusted to 200 $\mathrm{mL}$ with distilled water.

Preparation of pH 7.4 phosphate buffer: $50 \mathrm{~mL}$ of $0.2 \mathrm{M}$ monobasic potassium phosphate and $39.1 \mathrm{~mL} 0.2 \mathrm{M}$ of sodium hydroxide $(\mathrm{NaOH})$ were mixed and the volume was adjusted to $200 \mathrm{~mL}$ with distilled water.

\section{In vitro dissolution study}

Powder dissolution (n=3) of FBX (40 mg), PXM (41.89 mg), FBX-PXM physical mixture (1:1 molar ratio i.e. $40 \mathrm{mg}: 41.89 \mathrm{mg}$ ) and FBX-PXM cocrystal was performed using USP type II paddle dissolution test apparatus (Electrolab, Mumbai, India). All samples were passed through BSS \#sieve no. 40 and retained on BSS \#sieve no. 60 before dissolution studies. Dissolution studies were performed in $900 \mathrm{~mL}$ phosphate buffer $\mathrm{pH} 6.8\left(37 \pm 0.5^{\circ} \mathrm{C}\right)$, at $75 \mathrm{rpm} .{ }^{3,4} 5 \mathrm{~mL}$ aliquots were withdrawn at predetermined time points $(5,10,15,30,45$, 60 and $120 \mathrm{~min}$ ) substituting the same with an equal quantity of fresh dissolution media. Samples were filtered through $0.22 \mu$ nylon filters and analyzed by a validated HPLC method after suitable dilution with the mobile phase. Dissolution profiles of pure drugs and FBXPXM cocrystals were determined with respect to amount of drug dissolved at $15 \min \left(\mathrm{Q}_{15}\right), \%$ dissolution efficiency (DE) at 45 min and similarity factor using DDsolver. ${ }^{5}$

\section{Flow and compression properties}

Flowability of the samples was measured in terms of angle of repose using fixed funnel method ( $n=3) .6$ Carr's index and Housner's ratio was calculated from bulk density and tapped density measurement. Aulton and Wells method was used to study the compression properties of the novel solid forms. ${ }^{7} 150 \mathrm{mg}$ of the sample was blended with $1 \%$ of magnesium stearate in a glass vial and processed as per the compression protocol given in Table S6. For a plastic material, the compact strength is $\mathrm{C}<\mathrm{A}<\mathrm{B}$, while for fragmenting 
materials, $\mathrm{A}=\mathrm{B}=\mathrm{C}$. In case of elastic materials, $\mathrm{A}$ and $\mathrm{C}$ compacts will cap or laminate and B will maintain the integrity but form a weak compact. Capping occurs when the top or bottom of the tablet fractures and/or breaks free from the rest of the tablet either partially or completely. It indicates poor compressibility of the blend used.

\section{Stability study}

These samples were stored in humidity chamber at $40^{\circ} \mathrm{C} \pm 2^{\circ} \mathrm{C}$ and $75 \% \pm 5 \% \mathrm{RH}$ for 3 months and periodically analyzed by DSC, PXRD and drug release by HPLC.

\section{References}

(1) Dezani, A. B.; Pereira, T. M.; Caffaro, A. M.; Reis, J. M.; Serra, C. H. d. R., Equilibrium solubility versus intrinsic dissolution: characterization of lamivudine, stavudine and zidovudine for BCS classification. Braz. J. Pharm. 2013, 49, 853-863.

(2) United State Pharmacopoeia 36, NF 31 2013, 1, 1209-10.

(3) Savjani, K.; Gajjar, A.; Savjani, J., Modified formulation of febuxostat: improved efficacy and safety. Int J Pharm Pharm Sci 2016, 8, 359-66.

(4) Yüksel, N.; Karataş, A.; Özkan, Y.; Savaşer, A.; Özkan, S. A.; Baykara, T., Enhanced bioavailability of piroxicam using Gelucire 44/14 and Labrasol: in vitro and in vivo evaluation. Eur J Pharm Biopharm 2003, 56, 453-459.

(5) Zhang, Y.; Huo, M.; Zhou, J.; Zou, A.; Li, W.; Yao, C.; Xie, S., DDSolver: an add-in program for modeling and comparison of drug dissolution profiles. The AAPS journal 2010, $12,263-271$.

(6) Carr, R. L., Evaluating flow properties of solids. Chem. Eng. 1965, 72, 163-168.

(7) Taylor, K. M.; Aulton, M. E., Aultons Pharmaceutics: The Design and Manufacture of Medicines. ed.; Elsevier: 2013. 


\section{Supplementary Figures}

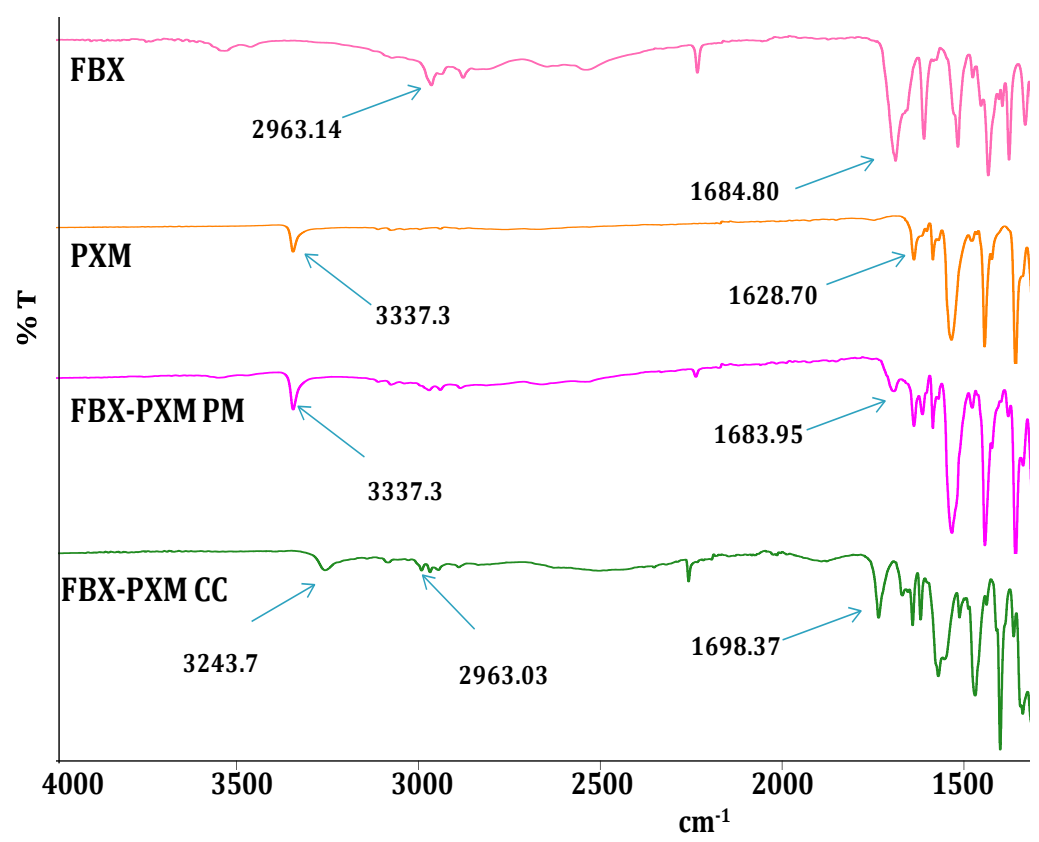

Figure S1: IR spectra of FBX, PXM, FBX-PXM PM (physical mixture) and FBX-PXM CC (cocrystal)

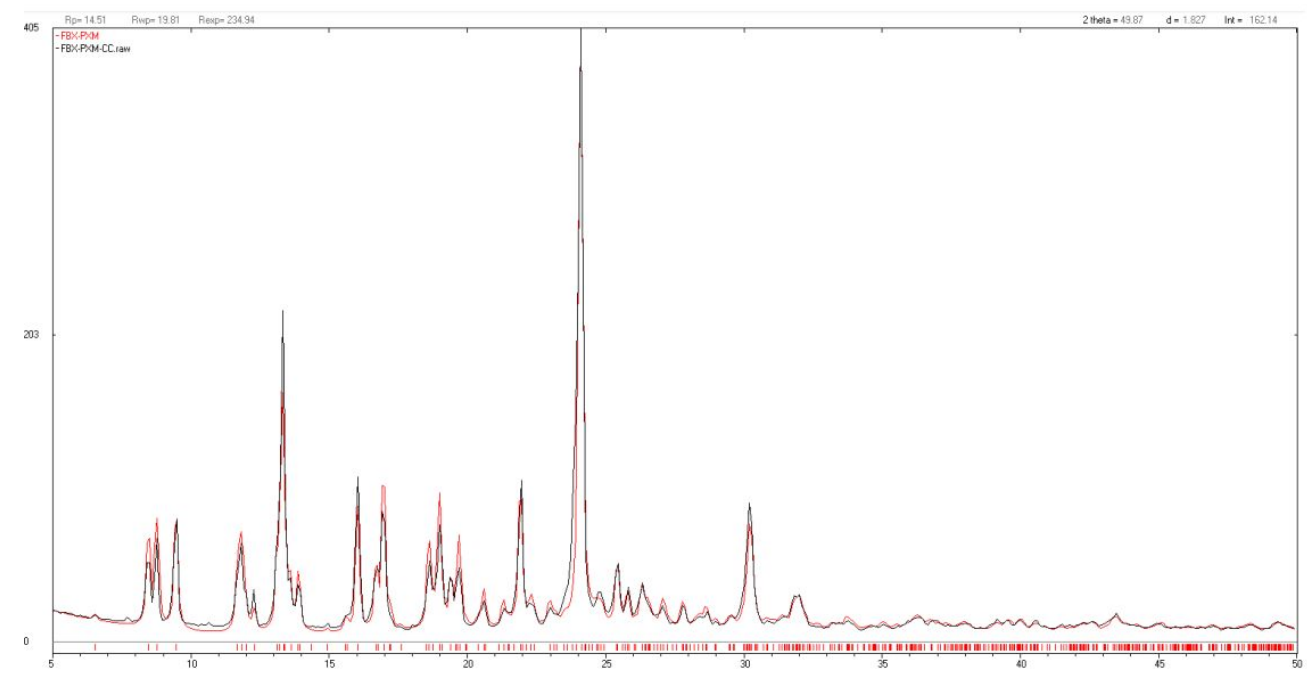

Figure S2 Overlay of superimposed experimental and simulated PXRD patterns of novel solid forms FBX-PXM (febuxostat-PXM cocrystal). (Red simulated pattern and black experimental pattern) with profile fitting parameters 


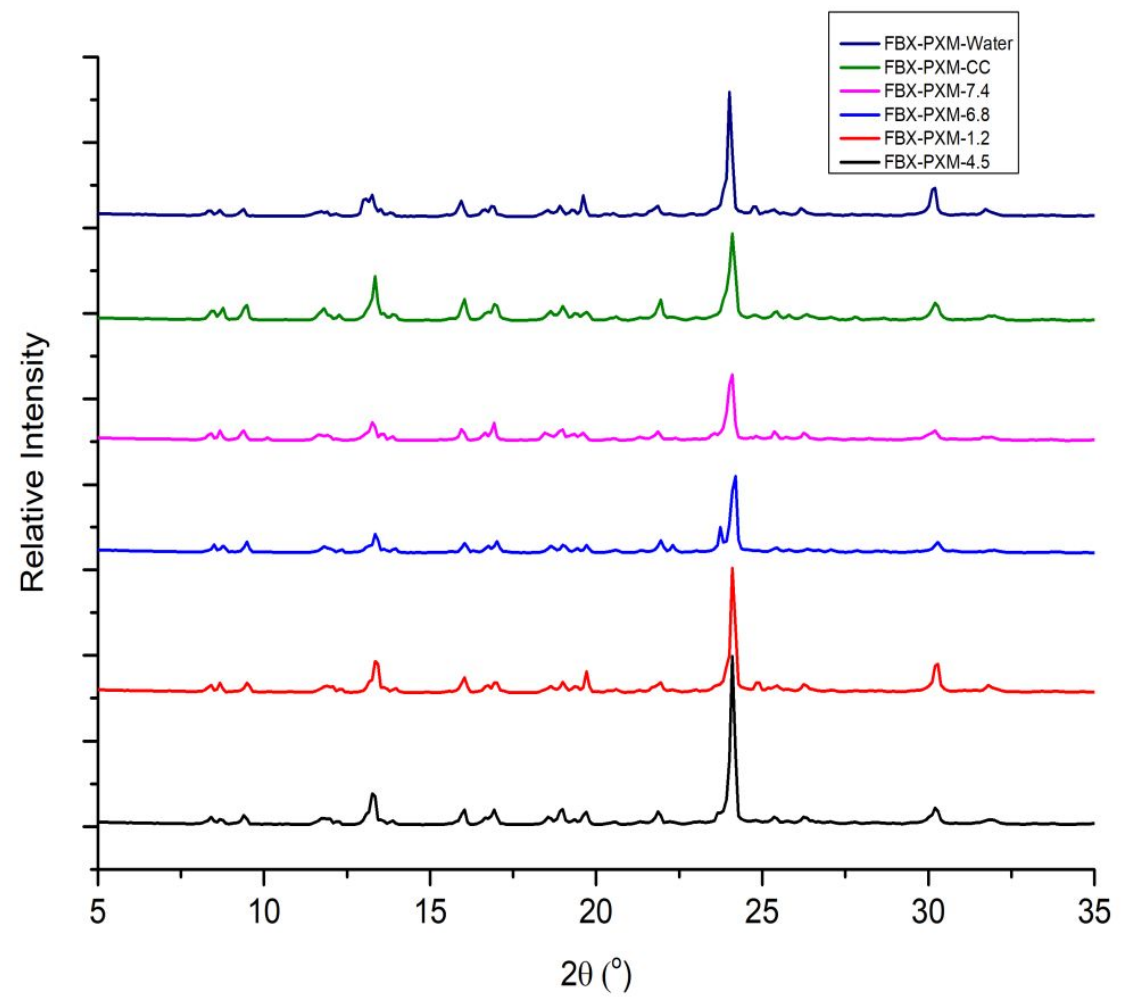

Figure S3 PXRD overlay of residual solubility samples of cocrystals in different buffers

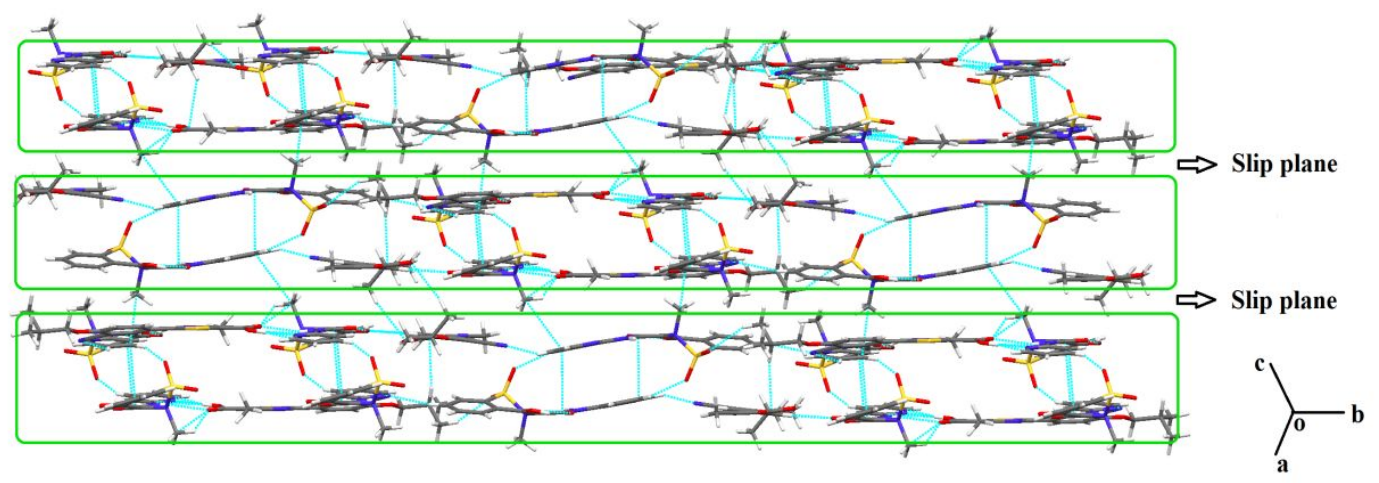

Figure S4 Crystal structure of FBX-PXM cocrystal showing slip plane system 

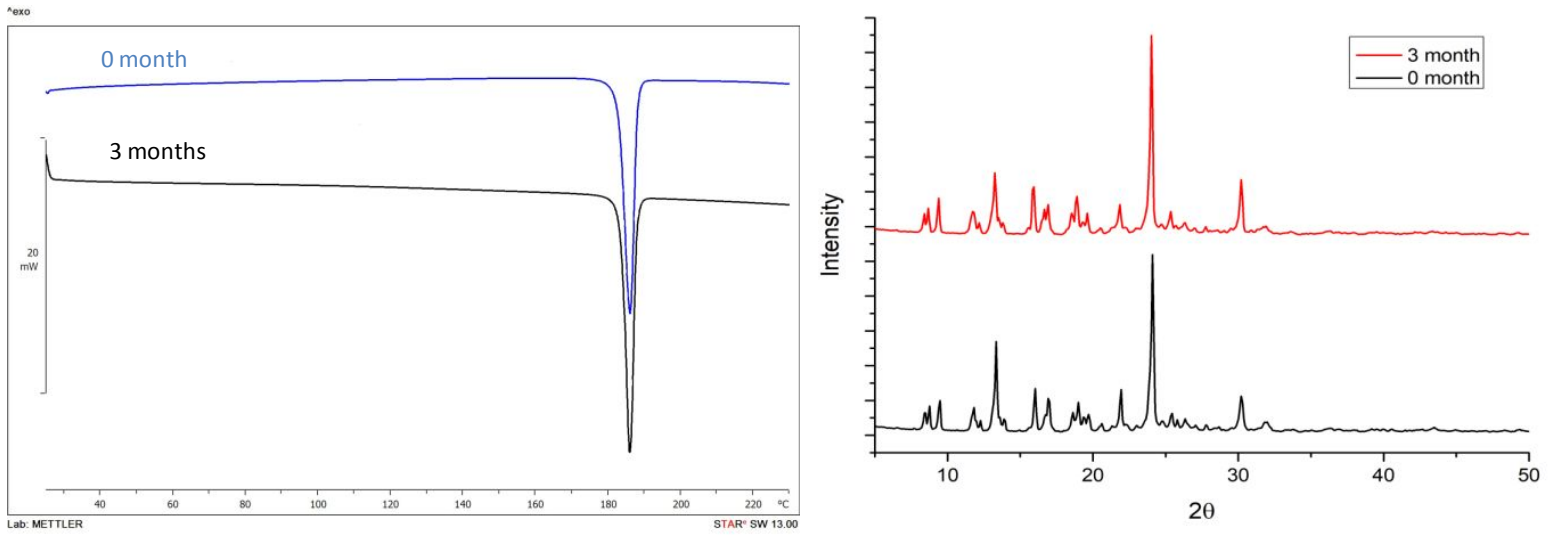

Figure S5 DSC and PXRD overlay of stability samples of 0 month and 3months FBX-PXM cocrystal

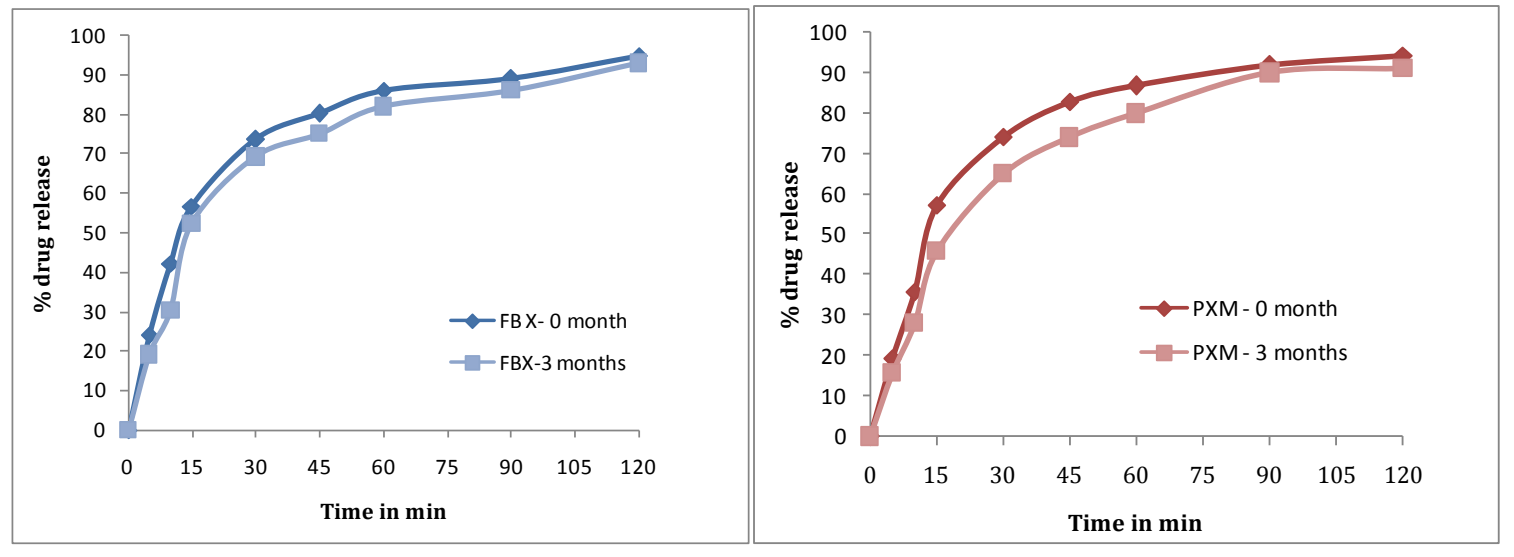

Figure S6 Dissolution profile of FBX (similarity factor $=60$ ) and PXM (similarity factor $=$ 56) from cocrystal after 3 months 


\section{Supplementary Tables}

Table S1 Onset, peak, endset and enthalpy values of DSC melting peaks of FBX, PXM, FBX-PXM CC (cocrystal)

\begin{tabular}{|l|l|l|l|l|}
\hline Compound & Onset $\left({ }^{\circ} \mathbf{C}\right)$ & Mid-point $\left({ }^{\circ} \mathbf{C}\right)$ & Endpoint $\left({ }^{\circ} \mathbf{C}\right)$ & Enthalpy $(\mathbf{J} / \mathbf{g})$ \\
\hline FBX & 209.02 & 210.05 & 213.46 & -145.53 \\
\hline PXM & 200.95 & 202.36 & 204.70 & -95.10 \\
\hline FBX-PXM CC & 183.03 & 184.95 & 188.54 & -111.74 \\
\hline
\end{tabular}

Table S2 IR stretching frequencies of FBX, PXM, FBX-PXM PM (physical mixture) and FBX-PXM CC (cocrystal)

\begin{tabular}{|c|c|c|c|c|c|c|c|}
\hline Compound & $\begin{array}{l}\text { C-N } \\
\text { stretch } \\
\left(\mathrm{cm}^{-1}\right)\end{array}$ & $\begin{array}{l}\mathrm{C} \equiv \mathbf{N} \\
\text { stretch } \\
\left(\mathrm{cm}^{-1}\right)\end{array}$ & $\begin{array}{l}\text { N-H } \\
\text { stretch } \\
\left(\mathrm{cm}^{-1}\right)\end{array}$ & $\begin{array}{l}\mathrm{C}=\mathrm{O} \\
\text { Carboxylic } \\
\text { stretch }\left(\mathrm{cm}^{-1}\right)\end{array}$ & $\begin{array}{l}\mathrm{C}=\mathrm{O} \\
\text { Amide } \\
\text { stretch }\left(\mathrm{cm}^{-1}\right)\end{array}$ & $\begin{array}{l}\text { O-H } \\
\text { stretch } \\
\left(\mathrm{cm}^{-1}\right)\end{array}$ & $\begin{array}{l}\mathrm{C}=\mathrm{N} \\
\text { stretch } \\
\left(\mathbf{c m}^{-1}\right)\end{array}$ \\
\hline FBX & - & 2229.42 & & 1684.8 & & 2963.14 & 1604.12 \\
\hline PXM & 1349.09 & - & 3337.31 & - & 1628.70 & - & - \\
\hline FBX-PXM PM & 1349.04 & 2229.35 & 3337.37 & 1683.95 & 1628.87 & - & 1605.26 \\
\hline FBX-PXM CC & $\begin{array}{l}1359.07 \\
1351.06\end{array}$ & 2228.88 & 3243.70 & 1698.37 & 1631.12 & 2963.05 & 1604.04 \\
\hline
\end{tabular}

Table S3 Profile fitting parameters of FBX-PXM cocrystal

\begin{tabular}{|c|c|c|c|}
\hline \multirow{2}{*}{ FBX-PXM cocrystal } & Rp & Rwp & Rexp \\
\cline { 2 - 4 } & 14.51 & 19.81 & 234.94 \\
\hline
\end{tabular}

Table S4 Hydrogen bond geometry in crystal structures

\begin{tabular}{|l|c|c|c|c|c|c|}
\hline Compound & Interaction & $\mathbf{d}(\mathbf{D}-\mathbf{H})$ & $\mathbf{d}(\mathbf{H} \cdots \mathbf{A})$ & $\mathbf{d}(\mathbf{D} \cdots \mathbf{A})$ & $<$ (DHA) & Symmetry code \\
\hline \multirow{5}{*}{$\begin{array}{l}\text { FBX-PXM } \\
\text { Cocrystal }\end{array}$} & $\mathrm{O} 2-\mathrm{H} 2 \mathrm{~A} \cdots \mathrm{N} 5$ & 0.92 & 1.78 & $2.690(2)$ & 171 & $\mathrm{x}, \mathrm{y}, \mathrm{z}$ \\
\cline { 2 - 7 } & $\mathrm{N} 4-\mathrm{H} 4 \mathrm{~A} \cdots \mathrm{O} 1$ & $0.84(3)$ & $2.34(3)$ & $3.158(2)$ & $162(2)$ & $\mathrm{x}, \mathrm{y}, \mathrm{z}$ \\
\cline { 2 - 7 } & $\mathrm{N} 4-\mathrm{H} 4 \mathrm{~A} \cdots \mathrm{N} 3$ & $0.84(3)$ & $2.34(3)$ & $2.761(2)$ & $111(2)$ & Intra \\
\cline { 2 - 7 } & $\mathrm{O} 6-\mathrm{H} 6 \mathrm{\cdots} \cdots \mathrm{O} 7$ & $0.91(3)$ & $1.65(3)$ & $2.517(2)$ & $159(3)$ & Intra \\
\cline { 2 - 7 } & $\mathrm{C} 11-\mathrm{H} 11 \cdots \mathrm{O} 6$ & 0.93 & 2.53 & $3.201(3)$ & 129 & $-1+\mathrm{x}, 1 / 2-\mathrm{y},-1 / 2+\mathrm{z}$ \\
\cline { 2 - 7 } & $\mathrm{C} 19-\mathrm{H} 19 \cdots \mathrm{N} 2$ & 0.93 & 2.61 & $3.488(4)$ & 157 & $1+\mathrm{x}, 3 / 2-\mathrm{y}, 1 / 2+\mathrm{z}$ \\
\cline { 2 - 7 } & $\mathrm{C} 28-\mathrm{H} 28 \cdots \mathrm{O} 7$ & 0.93 & 2.20 & $2.804(3)$ & 122 & Intra \\
\cline { 2 - 7 } & $\mathrm{C} 29-\mathrm{H} 29 \cdots \mathrm{O} 5$ & 0.93 & 2.40 & $3.239(3)$ & 150 & $1-\mathrm{x},-\mathrm{y}, 1-\mathrm{z}$ \\
\hline
\end{tabular}


Table S5 Chromatographic parameters

\begin{tabular}{|l|l|}
\hline Name & Specification \\
\hline Column & $\mathrm{C}-18(250 \times 4.6 \mathrm{~mm}, 5 \mu \mathrm{m})$ \\
\hline$\lambda_{\max }(\mathrm{nm})$ & $316(\mathrm{FBX}), 328(\mathrm{PXM})$ \\
\hline Linearity range $(\mu \mathrm{g} / \mathrm{mL})$ & $0.5-2.5$ \\
\hline Injection volume $(\mu \mathrm{L})$ & 10 \\
\hline Flow $(\mathrm{mL} / \mathrm{min})$ & 1.2 \\
\hline Elution & Isocratic \\
\hline Mobile phase & Methanol $+0.05 \%$ of ortho-phosphoric acid $(\mathrm{pH} 3)(80: 20)$ \\
\hline Retention time $(\mathrm{min})$ & $4.9(\mathrm{PXM}), 8.4(\mathrm{FBX})$ \\
\hline FBX equation & $\mathrm{y}=57122 \mathrm{x}-5 ., \mathrm{R}^{2}=0.998$ \\
\hline PXM equation & $\mathrm{y}=27568 \mathrm{x}+2928 ., \mathrm{R}^{2}=0.998$ \\
\hline
\end{tabular}

Table S6 Dissolution parameters of the generated cocrystals in comparison to plain drugs and physical mixture $(\mathrm{n}=3)$

\begin{tabular}{|c|c|c|c|c|c|c|}
\hline $\begin{array}{c}\text { Dissolution } \\
\text { parameters }\end{array}$ & FBX & $\begin{array}{c}\text { FBX from } \\
\text { cocrystal }\end{array}$ & $\begin{array}{c}\text { FBX from } \\
\text { physical } \\
\text { mixture }\end{array}$ & PXM & $\begin{array}{c}\text { PXM from } \\
\text { cocrystal }\end{array}$ & $\begin{array}{c}\text { PXM from } \\
\text { physical } \\
\text { mixture }\end{array}$ \\
\hline $\mathbf{D E}_{\mathbf{4 5}} \mathbf{( \% )}$ & 57.9 & 57.8 & 45.9 & 16 & 57 & 38 \\
\hline $\mathbf{Q}_{\mathbf{1 5}}$ & 59.02 & 56.59 & 45.09 & 11.03 & 57.25 & 34.08 \\
\hline
\end{tabular}

Table S7 Wells protocol for studying compressibility $(\mathrm{n}=3)$

\begin{tabular}{|l|c|c|c|}
\hline Sample amount & \multicolumn{1}{|c|}{$150 \mathrm{mg}+1.5 \mathrm{mg}$ magnesium stearate } \\
\hline Sample code & $\mathrm{A}$ & $\mathrm{B}$ & $\mathrm{C}$ \\
\hline Blending time & $5 \mathrm{~min}$ & $5 \mathrm{~min}$ & $30 \mathrm{~min}$ \\
\hline \multicolumn{2}{|c|}{ Compression using $8 \mathrm{~mm}$ die at $25 \mathrm{~kg} / \mathrm{cm}^{2}$ pressure } \\
\hline Dwell time & $2 \mathrm{~s}$ & $30 \mathrm{~s}$ & $2 \mathrm{~s}$ \\
\hline \multicolumn{3}{|r|}{ Equilibration in closed glass vials for 24 hour } \\
\hline \multicolumn{3}{|r|}{ Tablet crushing strength measurement } \\
\hline
\end{tabular}

Table S8 Flow properties and compressibility parameters $(n=3)$

\begin{tabular}{|l|c|c|c|}
\hline Drug/ parameter & Angle of repose ( $)$ & Carr's index (\%) & Housner's ratio \\
\hline FBX & $39.05 \pm 4.10$ & $23.53 \pm 2.86$ & $1.31 \pm 0.09$ \\
\hline PXM & $53.85 \pm 3.18$ & $26.92 \pm 1.23$ & $1.37 \pm 0.07$ \\
\hline FBX-PXM cocrystal & $22.00 \pm 0.35$ & $14.37 \pm 0.89$ & $1.12 \pm 0.03$ \\
\hline
\end{tabular}

